Reprinted with permission from: Environmental Entomology. 1995. 24(3):720-723.

Published and copyrighted by: ${ }^{\circ} 1998$ Entomological Society of America. www.entsoc.org

\title{
Temperature effects on the embryonic development of Aphthona abdominalis (Coleoptera: Chrysomelidae), a natural enemy of Euphorbia esula (Euphorbiales: Euphorbiaceae) ${ }^{1}$
}

\author{
LUCA FORNASARI
}

European Biological Control Laboratory, USDA-ARS, BP 4168-AGROPOLIS II, 34092 Montpellier Cedex 5, France.

\begin{abstract}
:
The flea beetle Aphthona abdominalis Duftschmid was selected as a candidate for biological control of Euphorbia esula L. (leafy spurge) in North America, where this introduced plant is a serious weed. The insect was collected and studied in Italy, where it occurs naturally. As part of the study of its life history, the effect of temperature on embryonic development was investigated at constant temperatures of 12, 15, 20, 25, 30, 35, 38 , and $41^{\circ} \mathrm{C}$, and variable temperatures were used as well. Survival and developmental rates were obtained. The median values used to calculate the time required for embryonic development through the thermal summation, a linear regression, and the logistic equation are discussed. The experimental data gave a developmental zero between 12 and $13^{\circ} \mathrm{C}$. Embryos completed their development at constant temperatures from 15 to $38^{\circ} \mathrm{C}$. Development required from $32.6 \mathrm{~d}$ at $15^{\circ} \mathrm{C}$ to only $4.5 \mathrm{~d}$ at $35^{\circ} \mathrm{C}$ constant temperatures. A. abdominalis was cleared and introduced into the United States during 1993.
\end{abstract}

Keywords:

Aphthona abdominalis, embryonic development, leafy spurge.

${ }^{1}$ Received for publication 22 April 1994; accepted 17 November 1994. 


\section{Introduction}

The flea beetle Aphthona abdominalis Duftschmid was released during 1993 in the United States (Montana and North Dakota) for the biological control of leafy spurge, Euphorbia esula L., a serious weed in North America (Dunn 1979). This poisonous plant, accidentally introduced into North America probably from Europe or Russia (Batho 1931, Dunn 1985) where it is not a problem, invaded rangelands and pastures of the northcentral United States and southern Canada, where it causes over 120 million dollars of losses annually (Watson 1985, Leitch et al. 1994). It is still spreading in North America, displacing natural vegetation and reducing the availability and value of land used for grazing (Watson 1985, Leitch et al. 1994). Because leafy spurge has a large pool of natural enemies in its area of origin, there is a good potential for a successful classical biological control program (Harris et al. 1985, Rees \& Spencer 1992, Fornasari et al. 1993). A. abdominalis was collected and studied in Italy, where it occurs naturally.

The life history (Fornasari 1993) and host specificity (Fornasari \& Pecora 1995) of $A$. abdominalis have been studied in the laboratory and in the field. The knowledge of the effect of temperature on the embryonic development of $A$. abdominalis is important for laboratory rearing and the use of this biological control agent in the field. The objective of the current study was to assess the effect of selected constant and variable temperatures on the embryonic development of $A$. abdominalis.

\section{Materials and methods}

Eggs of $A$. abdominalis were gathered from a colony of adults collected in the field in Italy (Tuscany) and reared in the laboratory. The adults were kept in plastic cages containing leafy spurge plants, on which the eggs were laid. The eggs for these studies were used within 4 hours of oviposition. They were collected using a fine camel's hairbrush and placed in 35-ml plastic cups provided with a layer of moistened plaster of Paris on the bottom. The effects of the following constant temperatures $\left( \pm 0.5^{\circ} \mathrm{C}\right)$, under $\mathrm{D}: \mathrm{D}$ photoperiod conditions, were evaluated: $12,15,20,25,30,35,38$, and $41^{\circ} \mathrm{C}$ (Table 1 ). The relative humidity inside the cups was $70-80 \%$. Groups of 20 eggs were placed in each cup and replicated 10-30 times for each temperature tested. A total of 2,685 eggs was studied at constant temperatures and 2,506 eggs at variable temperatures. The latter group of eggs was exposed at three environmental conditions having different daily mean temperatures: an outdoor cage, an unheated laboratory, and a heated laboratory. The cups containing the eggs for the studies at constant temperatures were placed into climatic cabinets. The number of hatched or collapsed eggs was recorded four times per day at 0800, 1200, 1600, and 2000 hours. The time required to control the eggs was $0.5-1$ min per cup. The time required for embryonic development was reported as days and hundredths of a day and also expressed as 100/y, which represents the average percent development made by the embryos per day, at the given temperature. For each temperature, the mean number of days to hatch, their standard deviation, and the percentage of survival at each temperature were then calculated. The data obtained were also subjected to linear and nonlinear regression to show the pattern of the effect of temperature on the development of the eggs. For this purpose the thermal summation and

Page 2 of 8 
For this purpose the thermal summation and the logistic equation (Davidson 1944) were also used.

These experiments were conducted at the former location of the European Biological Control Laboratory (EBCL) in Rome, Italy.

Table 1. Duration, speed of development (100/y), and mortality of the eggs of $A$. abdominalis under constant temperatures.

\begin{tabular}{|c|c|c|c|c|}
\hline Temp, ${ }^{\circ} \mathrm{C}$ & No. eggs & Mean $\pm \mathrm{SD}, \mathrm{d}$ & $100 / y$ & Mortality, \% \\
\hline 12 & 208 & - & - & 100.0 \\
\hline \multirow[t]{2}{*}{15} & 608 & $32.65 \pm 6.34^{\mathrm{a}}$ & $3.06^{\mathrm{a}}$ & 42.6 \\
\hline & & $39.36^{\mathrm{b}}$ & $3.08^{\mathrm{b}}$ & \\
\hline \multirow[t]{2}{*}{20} & 324 & $17.92 \pm 1.18^{\mathrm{a}}$ & $5.58^{\mathrm{a}}$ & 28.4 \\
\hline & & $14.23^{\mathrm{b}}$ & $7.39^{\mathrm{b}}$ & \\
\hline \multirow[t]{2}{*}{25} & 572 & $8.40 \pm 1.49^{\mathrm{a}}$ & $11.91^{\mathrm{a}}$ & 31.3 \\
\hline & & $8.68^{\mathrm{b}}$ & $11.70^{\mathrm{b}}$ & \\
\hline \multirow[t]{2}{*}{30} & 219 & $5.22 \pm 0.57^{\mathrm{a}}$ & $19.15^{\mathrm{a}}$ & 32.0 \\
\hline & & $6.25^{\mathrm{b}}$ & $16.02^{\mathrm{b}}$ & \\
\hline \multirow[t]{2}{*}{35} & 307 & $4.53 \pm 0.81^{\mathrm{a}}$ & $22.07^{\mathrm{a}}$ & 36.5 \\
\hline & & $4.88^{\mathrm{b}}$ & $20.33^{\mathrm{b}}$ & \\
\hline \multirow[t]{2}{*}{38} & 220 & $5.08+1.19^{\mathrm{a}}$ & $19.67^{\mathrm{a}}$ & 48.6 \\
\hline & & $4.31^{\mathrm{b}}$ & $22.92^{\mathrm{b}}$ & \\
\hline 41 & 227 & - & - & 100.0 \\
\hline
\end{tabular}

-, Not applicable.

${ }^{a}$ Observed.

${ }^{\mathrm{b}}$ Calculated.

\section{Results and discussion}

Constant Temperatures. The time required for development under constant temperatures ranged between $4.5 \pm 0.81$ and $32.6 \pm 6.34 \mathrm{~d}$, at 35 and $15^{\circ} \mathrm{C}$, respectively, and the calculated values range between 4.3 and $39.4 \mathrm{~d}$ (Table 1). The data are presented graphically in Fig. 1 and show a very good correlation between the observed and calculated values. The relationship between duration of egg development and temperature is represented by a hyperbola (Fig. 1), which has its asymptote at $12.06 \pm 0.92^{\circ} \mathrm{C}$ and a thermal constant (Thc) of $111.40 \pm 18.29$ DD (Table 2). This calculated developmental zero agrees with the experimental data, because no development was observed at $12^{\circ} \mathrm{C}$ and $57.4 \%$ of the eggs hatched at $15^{\circ} \mathrm{C}$. 


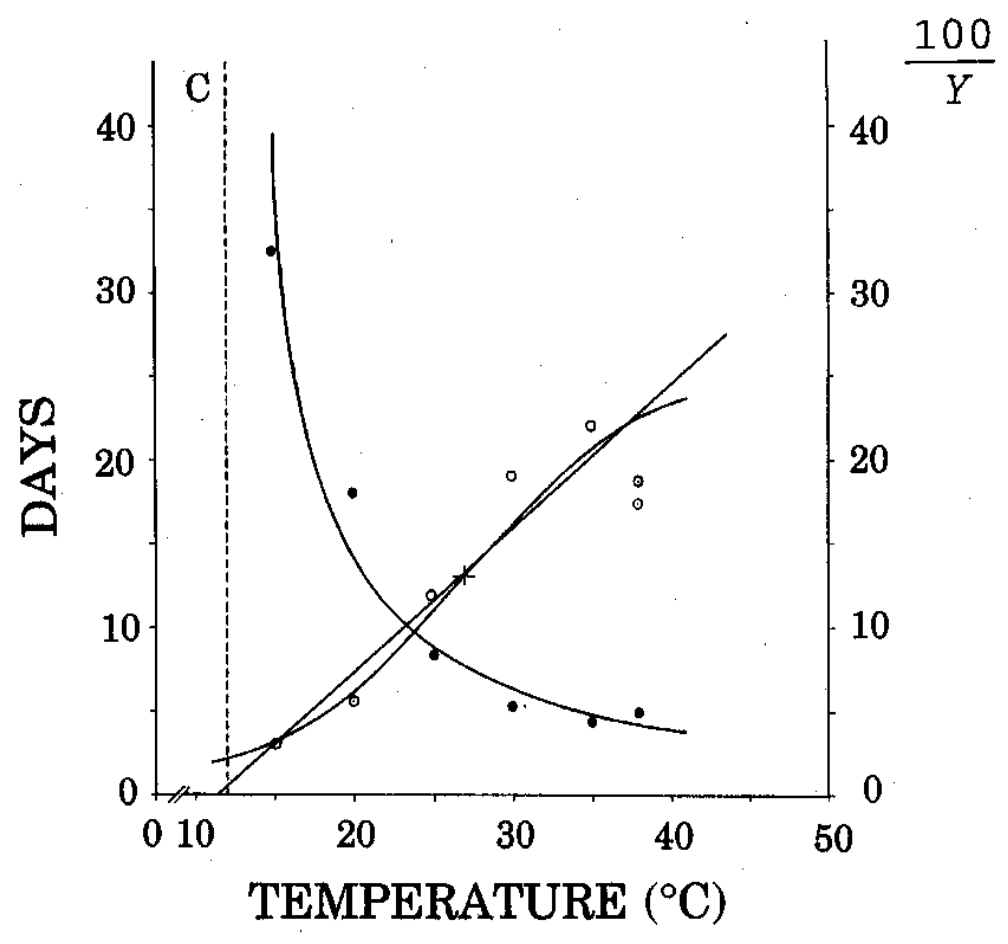

Fig. 1. Duration (days) and rate (100/y) of development of the eggs of $A$. abdominalis under constant temperatures. Developmental zero (c, dotted line) for the thermal summation and the linear regression is reported. The flex point of the logistic curve is also shown $(x=$ 27.045, $y=13.169$ ). Observed points are reported as closed circles (days) and open circles $(100 / y)$.

The rate of development is expressed by a linear regression and a sigmoid logistic curve in Fig. 1, where the reciprocals for developmental time are plotted against temperature. The high correlation coefficient for the linear regression (0.96, Table 2$)$ shows the good correlation between temperature and rate of development (Fig. 1). The The obtained was 115.9 DD for linear regression and 91.1 DD for the sigmoid curve (Table 2). The sigmoid curve better expresses the course of the rate of development, especially at lower temperatures. The developmental zero obtained using the three methods (Table 2) was similar for the thermal summation $\left(12.1 \pm 0.9^{\circ} \mathrm{C}\right)$ and the linear regression $\left(11.4^{\circ} \mathrm{C}\right)$, but lower for the logistic curve $\left(6.2^{\circ} \mathrm{C}\right)$. This underestimate of the lower threshold for development by the logistic curve has also been observed for other insects (Crovetti et al. 1981, 1982; Belcari \& Loi 1983; Loi \& Fornasari 1985). 
Table 2. Equations and constants characteristic for the eggs of $A$. abdominalis (under constant temperatures).

\begin{tabular}{ll}
\hline Thermal summation curve & $y(x-12.17)=111.40 \mathrm{DD}$ \\
& $c=12.06 \pm 0.92$ \\
& $\mathrm{Thc}=111.40 \pm 18.29 \mathrm{DD}$ \\
& $y=0.863 x-9.865$ \\
$r$ & $=0.957$ \\
& $c=11.43$ \\
Linear regression curve & $\mathrm{Thc}=115.91 \mathrm{DD}$ \\
& $100=\frac{26.337}{1+\mathrm{e}^{4.37924465-0.16192618 x}}$ \\
& $\mathrm{Flex} ; x=27.0, y=13.2$ \\
& $c=6.17$ \\
Logistic curve & $\mathrm{Thc}=91.12 \mathrm{DD}$ \\
& $100 \%=10.7^{\circ} \mathrm{C}$ cold, $42.1^{\circ} \mathrm{C}$ warm \\
& $50 \%=16.7^{\circ} \mathrm{C}$ cold, $36.1^{\circ} \mathrm{C}$ warm \\
& $25 \%=22.1^{\circ} \mathrm{C}$ cold, $30.7^{\circ} \mathrm{C}$ warm \\
Mortality & Min. $(18.8 \%)=26.4^{\circ} \mathrm{C}$ \\
\hline
\end{tabular}

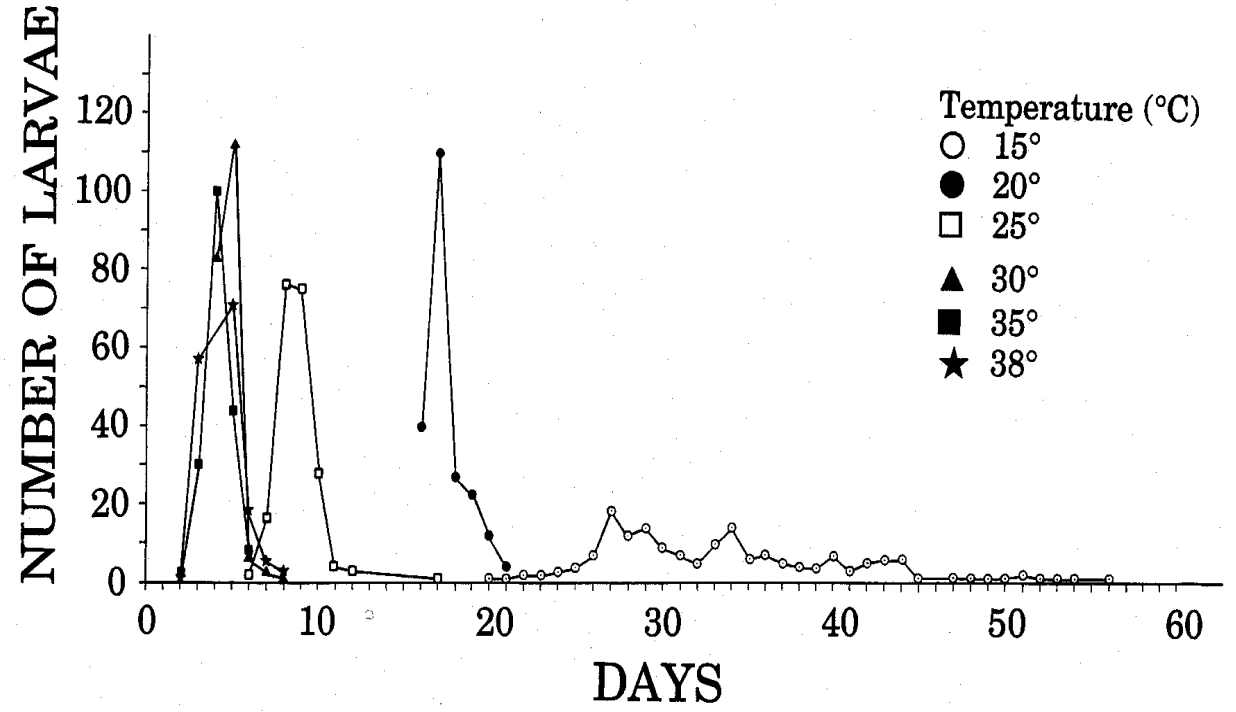

Fig. 2. Temporal distribution of hatching for eggs of $A$. abdominalis kept at constant 15, 20, $25,30,35$, and $38^{\circ} \mathrm{C}$. 
Figure 2 shows the distribution in time of hatching at the various constant temperatures tested ( $n=232$ at each temperature). Eggs held at temperatures of $20,25,30,35$, and $38^{\circ} \mathrm{C}$ had a small and rather uniform variation in the time needed to develop. On the contrary, hatches at $15^{\circ} \mathrm{C}$ were spread over a long period (Fig. 2). No eggs hatched at 12 and $41{ }^{\circ} \mathrm{C}$.

The mortality of the eggs kept under constant temperatures (Table 1) is graphically interpolated as a parabola (Fig. 3). The apparently high mortality recorded, also at optimal temperatures under constant temperature regimes, is the result of the fact that eggs laid

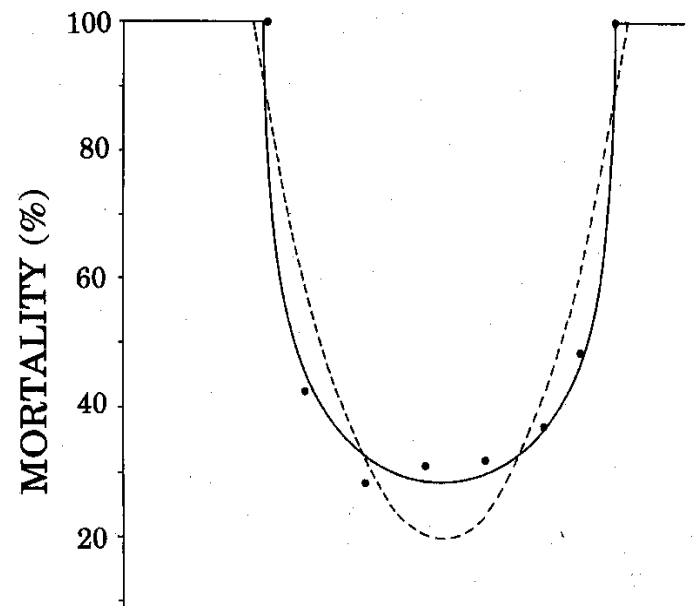

Fig. 3. Mortality curve for the eggs of $A$. $a b$ dominalis under constant temperatures, obtained from experimental data interpolated (solid line) curve and calculated (dotted line) curve.

different generations were used in these studies; the average high mortality reflects the variations in fertility at different times of the year (Fornasari 1993). The eggs laid at different times of the year were homogeneously distributed in the groups tested at each temperature. A mortality of $100 \%$ is reached at the extremes of 10.7 and $42.1^{\circ} \mathrm{C}$ (Table 2), whereas $50 \%$ mortality is reached at 16.7 and $36.1^{\circ} \mathrm{C}$ and $25 \%$ at 22.1 and $30.7^{\circ} \mathrm{C}$. The minimum mortality $(18.8 \%)$ is estimated to be at $26.4^{\circ} \mathrm{C}$.

Variable Temperatures. The time required for development under variable temperatures is reported in Table 3. This information allows a better understanding of the biology of this flea beetle in the field. During these studies, 35 groups of eggs were kept under different mean temperatures, ranging from 16.2 to $26.3^{\circ} \mathrm{C}$, with extremes from 11 to $34^{\circ} \mathrm{C}$ (Table 3). The effect of variable temperatures is evident in speeding up development (Table 3), if compared with constant temperatures (Table 1). In fact, it is known (see also Wigglesworth 1972) that usually variable temperatures lead to a faster development, provided the high and low values fall within the extreme thermal limits for that species. For instance, at constant 15 and $20^{\circ} \mathrm{C}$, embryonic development took $\approx 33$ and 18 days, respectively (Table 1 ), whereas with a mean temperature of $\approx 16$ (range, $13-20^{\circ} \mathrm{C}$ ) and $20^{\circ} \mathrm{C}$ (range, $12-31^{\circ} \mathrm{C}$ ) it took about half as long $(\approx 15$ and 11 days, respectively) (Table 3). The temperature variation during the period of the experiment ranged between 4 and $18^{\circ} \mathrm{C}$ (Table 3 ). The mortality ranged from 1.9 to $36.5 \%$, except for a group of 124 eggs laid on 17 October, which had a mortality of $73.4 \%$. Nevertheless, the high mortality in this group of eggs was very likely caused by their lower fertility at that time of the year. 
Table 3. Observed values of the duration, speed of development (100/y), and mortality of the eggs of $A$. abdominalis under variable temperatures.

\begin{tabular}{|c|c|c|c|c|c|c|c|}
\hline \multicolumn{4}{|c|}{ Temp. ${ }^{\circ} \mathrm{C}$} & \multirow[b]{2}{*}{$\begin{array}{l}\text { Mean development } \\
\text { time }(\text { days } \pm \text { SD) }\end{array}$} & \multirow[b]{2}{*}{$100 / y$} & \multirow[b]{2}{*}{ No. eggs } & \multirow[b]{2}{*}{ Mortality, $\%$} \\
\hline Mean & Max & Min. & Range & & & & \\
\hline 16.16 & 19 & 13 & 6 & $17.12 \pm 0.762$ & 5.842 & 60 & 28.4 \\
\hline 16.27 & 20 & 14 & 6 & $13.41 \pm 1.244$ & 7.459 & 120 & 20.0 \\
\hline 16.42 & 20 & 14 & 6 & $14.02 \pm 1.781$ & 7.133 & 60 & 11.7 \\
\hline 17.34 & 20 & 14 & 6 & $13.90 \pm 1.374$ & 7.193 & 60 & 31.7 \\
\hline 17.90 & 20 & 15 & 5 & $12.44 \pm 0.831$ & 8.039 & 60 & 31.7 \\
\hline 18.40 & 20 & 16 & 4 & $12.48 \pm 0.782$ & 8.014 & 100 & 10.0 \\
\hline 18.80 & 24 & 11 & 13 & $13.80 \pm 0.523$ & 7.246 & 27 & 25.9 \\
\hline 18.90 & 20 & 16 & 4 & $11.59 \pm 1.435$ & 8.628 & 140 & 12.9 \\
\hline 18.94 & 24 & 11 & 13 & $14.39 \pm 1.153$ & 6.949 & 54 & 33.4 \\
\hline 19.16 & 25 & 12 & 13 & $11.46 \pm 0.505$ & 8.727 & 119 & 10.1 \\
\hline 19.69 & 25 & 12 & 13 & $13.12 \pm 0.823$ & 7.619 & 42 & 4.8 \\
\hline 20.06 & 25 & 12 & 13 & $13.19 \pm 1.220$ & 7.581 & 115 & 13.1 \\
\hline 20.25 & 27 & 14 & 13 & $11.38 \pm 0.932$ & 8.783 & 75 & 13.3 \\
\hline 20.29 & 31 & 14 & 17 & $7.84 \pm 0.986$ & 12.758 & 37 & 0 \\
\hline 20.36 & 26 & 14 & 12 & $11.83 \pm 1.097$ & 8.454 & 40 & 12.5 \\
\hline 20.80 & 27 & 12 & 15 & $9.52 \pm 0.601$ & 10.500 & 25 & 16.0 \\
\hline 21.28 & 30 & 13 & 17 & $6.61 \pm 0.650$ & 15.120 & 98 & 10.3 \\
\hline 21.40 & 27 & 15 & 12 & $5.64 \pm 0.773$ & 17.716 & 49 & 8.2 \\
\hline 21.60 & 24 & 19 & 5 & $7.03 \pm 1.131$ & 14.224 & 124 & 73.4 \\
\hline 21.68 & 31 & 13 & 18 & $5.59 \pm 1.202$ & 17.891 & 59 & 5.1 \\
\hline 22.10 & 31 & 13 & 18 & $5.41 \pm 1.009$ & 18.467 & 97 & 3.1 \\
\hline 22.26 & 30 & 17 & 13 & $5.67 \pm 0.766$ & 17.647 & 25 & 30.0 \\
\hline 22.80 & 25 & 20 & 5 & $9.06 \pm 2.462$ & 11.034 & 20 & 20.0 \\
\hline 23.00 & 24 & 19 & 5 & $6.80 \pm 1.086$ & 14.697 & 128 & 24.2 \\
\hline 23.10 & 24 & 20 & 4 & $8.02 \pm 2.647$ & 12.462 & 260 & 36.5 \\
\hline 23.74 & 30 & 17 & 13 & $3.92 \pm 1.277$ & 25.517 & 46 & 19.57 \\
\hline 23.80 & 27 & 20 & 7 & $9.00 \pm 2.405$ & 11.111 & 37 & 21.60 \\
\hline 23.90 & 25 & 20 & 5 & $5.39 \pm 1.377$ & 18.556 & 23 & 21.70 \\
\hline 24.24 & 30 & 17 & 13 & $6.92 \pm 1.212$ & 14.457 & 25 & 40 \\
\hline 24.55 & 29 & 17 & 12 & $6.67 \pm 0.985$ & 21.483 & 105 & 27.6 \\
\hline 24.76 & 27 & 20 & 7 & $7.36 \pm 1.761$ & 13.580 & 90 & 14.5 \\
\hline 25.10 & 27 & 18 & 9 & $6.72 \pm 1.337$ & 14.876 & 75 & 28.0 \\
\hline 25.60 & 27 & 23 & 4 & $6.68 \pm 0.556$ & 14.970 & 27 & 7.4 \\
\hline 25.72 & 27 & 23 & 4 & $9.81 \pm 2.449$ & 10.196 & 32 & 18.75 \\
\hline 26.30 & 34 & 21 & 13 & $4.67 \pm 0.683$ & 21.428 & 52 & 1.90 \\
\hline
\end{tabular}




\section{Acknowledgments}

I express my appreciation to C. J. De Loach (Grassland, Soil, and Water Research Laboratory, Temple, TX), L. Knutson (EBCL, Montpellier, France), A. A. Kirk (EBCL), G. Loi (Pisa University, Italy), R. W. Pemberton (Asian Parasite Laboratory, Seoul, Korea), and P. C. Quimby (Rangeland Weeds Laboratory, Bozeman, MT) for critically reviewing the manuscript.

\section{References cited}

1. Batho, B. G. 1931. Leafy spurge. Manit. Dep. Agric. Immigr. Circ. 106.

2. Belcari, A. \& G. Loi. 1983. Influenza della temperatura sullo sviluppo dell'uovo di Chrysomela populi L. (Coleoptera: Chrysomelidae), pp. 661-667. Proceedings, XIII Italian National Congress of Entomology. Grafital, Torino, Italy.

3. Crovetti, A., G. Loi, F. Quaglin \& A. Belcari. 1981. Durata dello sviluppo dell'uovo di Dacus oleae (Gmel.) in a temperatura costante. Frustula Entomol. 4:83-91.

4. Crovetti, A., F. Quaglia, G. Loi, E. Rossi, P. Malfatti, F. Chesi, B. Conti, A. Belcari, A. Raspi \& B. Paparatti. 1982. Influenza di temperatura e umidita' sullo sviluppo degli stadi preimmaginali di Dacus oleae (Gmelin). Frustula Entomol. 5:133-166.

5. Davidson, J. 1944. On the relationship between temperature and rate of development of insects at constant temperatures. J. Anim. Ecol. 13:26-38.

6. Dunn, P. H. 1979. The distribution of leafy spurge (Euphorbia esula) and other weedy Euphorbia spp. in the United States. Weed Sci. 27:509-516.

7. 1985. Origins of leafy spurge in North America, pp. 7-13 In A. K. Watson [ed.], Leafy spurge. Monograph Series No. 3. Weed Science Society of America, Champaign, IL.

8. Fornasari, L. 1993. Life history of the flea beetle, Aphthona abdominalis Duftschmid, on Euphorbia esula L. (leafy spurge) in Italy. Biol. Control 3:161-175.

9. Fornasari, L. \& P. Pecora. 1995. Host specificity of A. abdominalis Duftschmid (Coleoptera: Chrysomelidae), a biological control agent for Euphorbia esula L, (leafy spurge, Euphorbiaceae) in North America. Biol. Control (in press).

10. Fornasari, L., L. Knutson, R. Sobhian, G. Campobasso, M. Cristofaro, A. Pastorino, R. Bennett \& A. Kirk. 1993. Overview of the U.S. Department of Agriculture Biocontrol of Weeds Laboratory-Europe, pp. 287-301. In M. G. Paoletti, T Napier, O. Ferro, B. Stinner \& D. Stinner [eds.], Socioeconomic and policy issues for sustainable farming systems. Cooperativa Amicizia, Padova, Italy.

11. Harris, P., P. H. Dunn, D. Schroeder \& R. Vomnoos. 1985. Biological control of leafy spurge in North America,. pp. 79-92. In A. K. Watson [ed.], Leafy spurge, Monograph Series, No. 3, Weed Science Society of America, Champaign, IL.

12. Leitch, J. A., F. L. Leistritz \& D. A. Bangsund. 1994. Economic effect of leafy spurge in the upper Great Plains: methods, models and results. Agricultural Economics Report No. 316, Agricultural Experiment Station, North Dakota State University, Fargo, ND.

13. Loi, G. \& L. Fornasari. 1985. Influenza della temperatura sullo sviluppo dell'uovo di Acanthoscelides obtectus (Say) (Coleoptera: Bruchidae). Frustula Entomol. 4:407-412.

14. Rees, N. E. \& N. R. Spencer. 1992. Biological control of leafy spurge. pp. 182-192. In L. F James, J. O. Evans, M. H. Ralphs \& R. D. Child [eds.], Noxious range weeds. Westview, Boulder, CO.

15. Watson, A. K. 1985. The leafy spurge problem. pp. 1-6. In A. K. Watson [ed.], Leafy spurge. Monograph Series No. 3. Weed Science Society of America, Champaign, IL,

16. Wigglesworth, V. B. 1972. The principles of insect physiology. Chapman \& Hall, London. 